\title{
Korku Sinemasında Yahudi Eksorsizm Geleneği Üzerine Fenomenolojik Bir İnceleme: The Unborn Filmi Örneği*
}

\author{
A Phenomenological Survey on Jewish Exorcism Tradition in Horror Movies \\ (Example of “The Unborn”)
}

Halit Ahmet ÇíFTÇi***

Öz

Abstract

Efsaneler ve masallar kutsalı ve kutsalın tarihini ifade Myths and fairy tales are extemporary ways of narrating etmeye yönelik doğaçlama bir biçimde gelişen anlatım the sacred and the history of it. Those are also archaic biçimleridir. Onlar aynı zamanda antik insanın çevresine man's way of explaining the phenomena relating to him ve kendine dair fenomenleri açıklama yoludur. Antik and his environment. With the aid of myths, he explains insan, döneminin bilimiyle veya algısılla the phenomena which he cannot explain with the anlamlandıramadığı olguları mitlerle açıklar. Bu olgular science and perception of his time. There are lots of arasında bazen kötü ruh inanışı şeklinde de tezahür myths about the jinn, demon and dead spirit which are eden cin, şeytan ve ölü ruh inanışları ve onların maddi sometimes believed as the evil spirits and their relations dünya ile ilişkileriyle ilgili olan mitler vardır. Cinlerin veya with the physical world. Beliefs relating to the possession şeytanların ve ölü ruhlarının, insanların bedenlerini ele of human souls by demons or evil spirits are very geçirerek onları rahatsı ettiği hatta zaman zaman popular among religious cultures all around the world. ölümlerine sebebiyet verdiği inanışı dünyanın dört bir Various kinds of talismans, amulets and protective tarafındaki dinsel toplulukların ve kültürlerin çoğunda objects are set up and exorcism rites are applied for yaygındır. Insanlar cinlerin veya kötü ruhların ele possessed people. Methods of these rites vary among geçirdiğini veya rahatsız ettiğini düşündüğü kişiler için different religions and cultures. Jewish exorcism has its bazı tilsımlar, koruyucu dua (muska) ve nesneler indas own methods and in this study these methods will be etmişler; eksorsizm adı verilen cin çıkarma ayinleri investigated with a phenomenological approach in the düzenlemişlerdir. Bu ayinlerin yapılış usulleri dinlere ve context of the movie "The Unborn" which is about Jewish kültürlere göre değişiklik göstermektedir. Yahudi exorcism. The aim of the study is to determine which geleneğindeki eksorsizmin de kendine has törensel principles of exorcism in Jewish folklore are seen in the uygulamaları vardır. Bu çalışmada bu uygulamalar movie and which phenomenological factors enrich the fenomenolojik bir yaklaşımla, Yahudi eksorsizmini konu movie.

alan The Unborn adlı sinema filmi bağlamında incelenecektir. Çalışmanın amacı, bahsi geçen filmde Yahudi folklorundaki eksorsizm prensiplerinin ne derece uygulandığını ve hangi fenomenolojik unsurların filme zenginlik kattı̆̆ını tespit etmektir.

Anahtar Kelimeler: Dinler Tarihi, Yahudilik, Eksorsizm, Keywords: History of Religions, Judaism, Exorcism, Şeytan/Cin, Dybbuk, Korku Sineması.

Demon/Jinn, Dybbuk, Horror Movies.

\section{Giriş}

Eksorsizm, Hollywood korku sinemasında gayet yaygın bir şekilde işlenen bir temadır. William Peter Blatty’nin aynı isimli romanından uyarlanmış olan 1973 yapımı The Exorcist $^{1}$ ve şeytanî tahakküm altında olduğu düşünülüp Katolik Kilisesi’nin piskoposluk düzeyinde verdiği izinle üzerinde yaklaşık bir sene boyunca uygulanan

* Geliş Tarihi: 11.02.2021, Kabul Tarihi: 08.05.2021.

** Dr. Öğr. Üyesi, Süleyman Demirel Üniversitesi, İlahiyat Fakültesi, Dinler Tarihi Anabilim Dalı, halitciftci@sbu.edu.tr, Orcid: 0000-0003-2037-6737.

1 https://www.imdb.com/title/tt0070047/?ref_=nv_sr_srsg_0 
eksorsizm ayinleri sonucunda yetersiz beslenmeden dolayı hayatını kaybeden Anneliese Michel'in (1952-1976) hayatını konu alan 2005 yapımı The Exorcism of Emily Rose ${ }^{2}$ adlı sinema filmleri bunların başında gelmektedir. Bahsi geçen filmler Hıristiyan eksorsizmi ile ilgili olup bildiğimiz kadarıyla Yahudi eksorsizm geleneği ile ilgili makalemizin konusunu oluşturan filmden başka bir film bulunmamaktadır. Ayrıca ülkemizde eksorsizmle ve cin/şeytan tahakkümüyle alakalı akademik çalışmaların yok denecek kadar az olması bu çalışmanın büyük ölçüde örnek teşkil edecek bir çalışma olma potansiyelini beraberinde getirmektedir. Çalışmamıza başlamadan önce cin, şeytan, kötü ruh, şeytan çıkarma gibi terimlerle ilgili genel bilgiler vermek yerinde olacaktır.

Cin/şeytan çıkarma uygulamasının karşılığı olarak Batı dillerinde kullanılan eksorsizm, eski Yunanca’da “kötü bir ruhu kovmak, bir yeminle/lânetle bağlamak” mânâlarına gelen “eksorkizo” kelimesinden gelmektedir. ${ }^{3}$ Etimolojisi düşünüldüğünde eksorsizm kelimesine "kötü bir ruhu bir lânetle/bedduayla bağlayıp etkisiz hale getirerek içine girdiği bedenden dışarı çıkarmak” gibi bir mânâ da verilebilir. Ancak Batı literatüründe eksorsizm kelimesi sadece kötü ruhun değil aynı zamanda şeytan veya cinin kovulması mânâsında da kullanılır. Eski Yunanca'da “iftira atmak, karalamak” mânâsındaki “diabol, diabole” kökünden gelen "Diabolos”, ${ }^{4}$ İngilizce’de aynı kökenden "Devil”, 5 Fransızca'da "Diable”, İtalyanca'da "Diavolo" ve İspanyolca’da “Diablo” olarak bilinen Şeytan veya “Diabolos”un bozulmuş hali olması muhtemel olan diğer adıyla İblis ise Batı kültüründe bütün kötülüklerin kaynağı ve sembolü olarak görülür. Günaha sevk eden, insanları ayartan, kötülüğe dair her şeyi kendisinde barındıran, Tanrı'ya ve Tanrı'ya dair ne varsa hepsinin düşmanıdır. Tanrı’ya başkaldıran ve bu yüzden Cennet’ten kovulan, düşürülen, mağrur ve asi bir melektir. ${ }^{6}$ Cennet’ten kovulma bağlamında kullanılan kavramlardan biri de demon veya https://www.imdb.com/title/tt0404032/?ref_=nv_sr_srsg_0

3 Henry George Liddell - Robert Scott, A Greek-English Lexicon, ed. Henry Stuart Jones (Oxford: Clarendon Press, 1996), "eksork-izo", 598.

4 Liddell - Scott, A Greek-English Lexicon, "diabol-i, e”, 390.

5 Ernest Klein, A Comprehensive Etymological Dictionary of the English Language, (Hollanda: Elsevier Publishing Company, 1966), “devil”, 1/437.

6 Giovanni Scognamillo - Arif Arslan, Doğu ve Batı Kaynaklarına Göre Şeytan, (İstanbul: Karizma Yayınlar1, 1999), 24. 
daimon’dur. Bu kavram Kitab-ı Mukaddes’te şeytan gibi kovulmuş melekler için kullanılan bir terim olup insanlarla melekler arasında bulunan bir varlık türü olarak da tanımlanır. Bazı tabiat dinlerinde insanüstü iyi veya kötü nitelikli metafizik ruhlar olarak düşünülmüştür. ${ }^{7}$

Cinlerin ve kötü ruhların insanlarla ilişkilerinden daha önce bahsetmiştik. Bu konu ile ilgili Ernst Zbinden Kuzey Fas’taki cin çıkarma ritüelleri bağlamında ilginç bir iddia ortaya atmıştır. Zbinden, cin çıkarmanın temel düşüncesini insan gücünün cinlere karşı duramayacağı ve bu yüzden çözüm olarak kötü cinin karşısına iyi yani mü’min cini koymak gerektiği şeklinde açıklamıştır. Bunun takdim şeklinin ise büyücünün işi ve sanatı olduğunu kaydetmiştir. ${ }^{8}$ Elbette bu iddia bütün cin çıkarmalar için geçerli değildir. Yahudi, Hıristiyan ve Müslüman gelenekleri başta olmak üzere birçok farklı coğrafyada ve kültürde birbirinden farklı prensiplere sahip birçok farklı eksorsizm ritüeli uygulanmaktadır. Ancak konuyu fazla dağıtıp okuyucuyu sıkmamak adına sadece birbirleriyle en fazla etkileşim içinde olan dinler olması hasebiyle Yahudi, Hıristiyan ve Müslüman geleneklerindeki eksorsizm ritüellerinden ve cin, şeytan ve kötü ruh inanışlarından kısaca bahsetmek uygun olacaktır. Bu bahiste kronolojiyi gözetmek yerine asıl konumuzun devamlılığını sağlamak adına Yahudilik en sona bırakılacak ve hemen sonrasında filmin fenomenolojik değerlendirmesine geçilecektir.

\section{Eksorsizm Uygulamaları ve Cin/Şeytan ve Kötü Ruh İnanışları}

Müslüman geleneğinde çeşitli eksorsizm ritüellerine rastlanmaktadır. İşbirliği içerisinde çalıştığını düşündükleri cinler aracılığıyla kötü niyetli cinler tarafından tahakküm altına alındığı düşünülen insanlara karşı uzaktan eksorsizm uyguladığını iddia edenler olduğu gibi çeşitli Kur’an ayetleri ve dualarla, okunmuş sularla, bizzat yüzyüze eksorsizm uygulayanlar da vardır. Zbinden'in de değindiği gibi burada önemli olan kötü cinin karşısına iyi yani mü’min cini koymaktır. “Cin” kelimesi Kur’an-ı Kerim’de

7 Şinasi, Gündüz, Din ve İnanç Sözlüğü, ed. Bekir Cantemir (İstanbul: Vadi Yayınları, 2017), “Demon”, 119.

8 Ernst, Zbinden, İslam'da ve Eski Ortadoğu'da Cin ve Ruh Inançları, Çev. Ekrem Sarıkçığlu, (İstanbul: Yeni Ufuklar Neşriyat, 1994), 33. 
sadece Mekkî surelerde geçer. Bazen “cânn” olarak geçtiği de görülür. ${ }^{9}$ Cânn’ın cinlerin atası olduğu tefsir edilmiştir. İblis olduğunu iddia edenler de olmuştur. ${ }^{10}$ Cinlerin $\mathrm{Hz}$. Süleyman’a yüksek ve görkemli binalar, heykeller, havuz gibi lengerler, yerinden kalkmaz kazanlar yaptığı anlatılır. ${ }^{11}$ Cinlerden bir ifrit Hz. Süleyman’a Sebe Melikesi'nin tahtını Hz. Süleyman yerinden kalkmadan getirebileceğini söyleyerek tahtı getirmek için izin ister. ${ }^{12}$ Bu bağlamda da cinlerin büyük mesafeleri kısa zamanda kat edebilen varlıklar olduğunu anlıyoruz. Bütün bunlara rağmen Hz. Süleyman’ın ölümünü

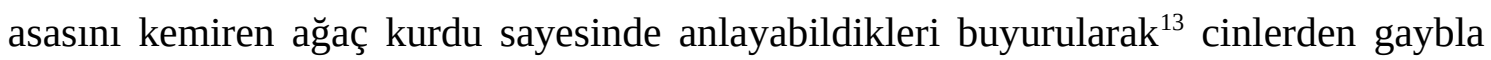
ilgili haberler almaya çalışanlara onların gaybı asla bilemeyecekleri bildirilmiştir.

Cin Suresi'nde cinlerin içinde inkarcılar olduğu gibi Hz. Muhammed’in sohbetini dinleyip iman edenlerin olduğu da belirtilir. Halk arasında genellikle canavar şeklinde çirkin ve korkunç görünümlü olarak tasvir edilen cinlerin Kur'an'da dumansız ateşten yaratıldıkları ifade edilmiştir. ${ }^{14}$ Kur'an'da İblis’in de cinlerden olduğu belirtilmiştir. ${ }^{15}$ Her ne kadar İslami bir dayanağı olmasa da cinlerin bazı insanlarla ilişki kurabilecekleri, insanlarla evlenip onlardan çocuk sahibi olabilecekleri, insanlarla çift taraflı etkileşime girebilecekleri yani onları kontrol altına alıp yine onlar tarafından kontrol altına alınabileceklerine inanılmaktadır. ${ }^{16}$

Tarihin her döneminde insanların yaşadığı bütün coğrafyalarda var olan cin, şeytan, kötü ruh gibi inanışlar Hıristiyan inancını da etkilemiştir. İncil yazarları derledikleri İncillerde Hz. İsa'ya atfettikleri birçok cin çıkarma hadisesine yer vermişlerdir. ${ }^{17}$ Katolik Kilisesi de 1545-1563 yılları arasında gerçekleştirilen ekümenik nitelikli Trent Konsili’nde Papalık’ın danışmanlığında hazırlanması istenen ibadet kitaplarından biri olan ve içeriğinde Vaftiz, Konfirmasyon, Günah Çıkarma, Son

9 Rahman, 55/15.

10 Ebü'l-Kasım Mahmud b. Ömer b. Muhammed el-Harizmi ez-Zemahşerî, el-Keşşaf, (İstanbul: Türkiye Yazma Eserler Kurumu Başkanlığı Yayınları, 2020), 6/507.

11 Sebe, 34/13.

12 Neml, 27/39.

3 Sebe, 34/14.

4 Hicr, $15 / 27$.

Kehf, 18/50.

6 Gündüz, Din ve İnanç Sözlüğü, 105.

17 Kitabı Mukaddes (İstanbul: Kitabı Mukaddes Şirketi, 2011) Mat.17:14-21; Mar.6:5; Luk.4:35. 
Yağlama, Cenaze Ayini, Evlilik gibi sakramentlerin yanısıra Şeytan Çıkarma başlığı altında bir bölüm bulunan Rituale Romanum ${ }^{18}$ adlı kitap aracılığıyla şeytan çıkarma ayinleri uygulanmasına izin vermektedir. ${ }^{19}$ Katolik Kilisesi tarafından 1975 yılında piskoposluk düzeyinde verilen izinle, şeytani tahakküm altında olduğu düşünülen Anneliese Michel isimli genç kadına 10 ay boyunca uygulanan şeytan çıkarma ayinleri sonucunda Michel hayatını kaybetmiş ve otopsi sonucunda ölüm nedeni yarı açlık halinde kötü beslenme ve susuzluk olarak kayıtlara geçmiştir. ${ }^{20}$ Katolik Azizleri de zaman zaman şeytan çıkarma ayinleri uygulamışlardır. Aziz Bernard (1090-1153) ile ilgili anlatılan bir efsaneye göre o, bir şeytanın musallat olduğu bir kadına asasını vermiş ve başucuna koymasını tavsiye etmiştir. Bundan sonra artık kadının odasına girmeye cesaret edemeyen şeytanın kadına sıkıntı vermeye devam etmesinden dolayı Aziz Bernard, halka ellerinde yanan mumlarla gelmelerini emretmiş ve gerçekleştirilen toplu bir ayinle şeytanı kovup kadını kurtarmışlardır. ${ }^{21}$

Kitab-ı Mukaddes’te ve Yahudi geleneğinde cin inancı veya cin çıkarma ile ilgili pek fazla bilgiye rastlanmaz. İsrail'in resmi dini, şeytanlara biçilen ve Kitab-ı Mukaddes'te uygulamada hiç bulunmayan roller hususunda zamanın politeist kültürleriyle tamamen zıt bir görüntü çizer. Büyü, İsrailoğulları arasında çok erken dönemlerden beri yasaklanmıştır. Tevrat’ın Çıkış Kitabı’nda büyücü kadına müsamaha gösterilmemesi emredilmiş ${ }^{22}$ ve Talut'un ruh çağıranları ülkeden kovduğundan bahsedilmiştir. ${ }^{23}$ Pagan büyüsünün büyük bir kısmı koruyucu yani şeytanları uzakta tutmaya veya onları kovmaya yönelik olduğu için İsrail dini şeytani faaliyetleri engellemeye çalışmıştır. Zira Tevrat’taki “Rabb’in onayı olmadan bir kentin başına felaket gelir mi?” ifadesinden hareketle afet ve hastalıkların Rab tarafından

18 James, Lecoffre vd. (Ed.) Rituale Romanum, (ABD: Firmin Didot Freres, 1855), 474.

19 J. M. Pierce, "Roman Ritual", New Catholic Encyclopedia, ed. Berard Lawrence Marthaler, (ABD: Thomson Gale, 2003), 12/258.

20 Anneliese Michel ile ilgili ayrıntılı bilgi için bkz.: Halit Ahmet Çiftçi, Bir Hıristiyan Apolojist Olarak Aziz Justin Martyr, (Isparta: Süleyman Demirel Üniversitesi, Sosyal Bilimler Enstitüsü, Doktora Tezi, 2017), 61-63.

21 Heinrich Kramer, The Hammer of Witches: A Complete Translation of the Malleus Maleficarum, çev. Christopher S. Mackay, (ABD: Cambridge University Press, 2009), 417-418.

22 Çık.22:18.

23 1Sa.28:3. 
gönderildiğine inanılırdı. Her ne kadar Tanrı iradesini daima hemen yerine getirmese de melekleri ve ruhları aracılar olarak kullanması, ruhların O’nun kontrolünde olduğunu açıklığa kavuşturur. Nitekim Talut’a sıkıntı çektiren kötü ruhun “Tanrı’dan gelen bir kötü ruh”24 olduğu ifade edilmiştir. Bu yüzden Kutsal Kitap’ta cin inancına dair muhtelif izlerin çok fazla önemli olmadığı veya onların yorumlanmasındaki güçlüklerin hafife alınmaması gerektiği belirtilmiştir. Söz konusu pasajların çoğu şiirsel olup ismi geçen cinin yaşayan dini inancın mı bir parçası olduğu yoksa sadece geleneksel edebi dilin mi bir parçası olduğunu belirlemenin çoğu kez imkansız olduğu kaydedilmiştir. ${ }^{25}$ Zbinden Tevrat’ta Yaratılış 32'de Yakub’un Tanrı olduğu düşünülen bir adamla güreştiğinin anlatıldığı anekdottaki kişinin bir cin olduğunu ve Yahve’nin cinlere atfedilen bütün işleri kabul ettiği gibi bu olayı da üzerine aldığını düşünmüştür. I. Samuel 5’te de Ahid Sandığı ile ilgili hikâyede Yahve’nin Aşdotluları ve çevrelerindeki halkları ağır biçimde cezalandırıp onları urlarla sıkıntıya soktuğu anlatılmış ve ülkelerinde ortaya çıkıp ölüm saçan fareler cin olarak kabul edilmiştir. ${ }^{26} \mathrm{Bu}$ kısımdaki fare istilası ile ilgili cümle masoretik metinde geçmeyip Septuaginta’da bulunmaktadır.

\section{The Unborn (Doğmamış) Filmi Bağlamında Yahudi Eksorsizm Geleneği}

Yönetmenliğini ve senaristliğini anne tarafından bir Yahudi olan David Samuel Goyer'in yaptığı ve başrollerini Odette Annable, Gary Oldman ve Cam Gigandet’in paylaştığı 2008 yapımı The Unborn (Doğmamış) adlı film, Odette Annable’in canlandırdığı Casey Beldon isimli genç bir kadının kendisine ve karnındaki doğmamış bebeğine musallat olan, iki dünya arasına sıkışıp kalmış kötü bir ruhla mücadelesini konu edinmektedir. İntihar ettiği için annesinden nefret eden Casey, uyurken gördüğü kâbusları artık uyanıkken de görmeye başlayınca durumdan babasına bahseder ve babasından anne karnındayken Casey’nin göbek kordonunun boynuna dolanması sonucu ölen bir ikiz erkek kardeşi olduğunu öğrenir. Erkek kardeşi ölmüş olmasına

24 1Sa.16:14

25 Delbert Roy Hillers, "Demonology", Encyclopedia Judaica, ed. Fred Skolnik (ABD: Thomson Gale, 2007), 5/572.

26 Zbinden, Cin ve Ruh Inançlarl, s. 141. 
rağmen ona musallat olan iki dünya arasına sıkışıp kalmış kötü bir ruh (dybbuk) Casey’ye ve doğmamış çocuğuna musallat olmuştur. ${ }^{27}$

Burada iki dünya arasına sıkışıp kalmış kötü ruh ifadesine bir parantez açmak gerekmektedir. Musevi kaynaklarında, yaşayan bir insanın vücudunu ele geçiren bir ölü ruhunu ifade etmek için “dybbuk” terimi kullanılır. Bu terime ilk olarak XVII. yüzyıl Aşkenazi Yahudi kaynaklarında rastlanır. Daha erken Yahudi kaynakları ve Sefarad Yahudileri XVII. yüzyıldan sonra bile şeytanların ele geçirdiği düşünülen kişiler için kötü bir ruha yapışmış manasında “davuk mi-ruah ra’ah” ifadesini kullanırlar. Aşkenazi kullanımı fiilin “yapışmak” manasındaki kökünü ödünç alarak “yapışan” şeklinde isim haline dönüştürmüştür. ${ }^{28}$ Dybbuk inancının üzerinde oturduğu temel, ruh göçü fikridir. Aslında Yahudiliğin erken dönemlerinde bulunmayan ancak XII. yüzyılda Yahudi mistisizmi Kabbala'nın ilk metinlerinden sayılan Sefer ha-Bahir ile birlikte kavramsal düzleme oturtulan ruh göçü fikri, ölen günahkâr insanın işlediği günahların cezasını çekmesi için Tanrı tarafından farklı bir bedende tekrar dünyaya gönderilmesidir. Bu şekilde dünyaya yeniden gelen ruh iyi işler yaparak daha önce işlemiş olduğu günahları temizler ve öldükten sonra diğer iyi amel sahiplerinin ruhları gibi ilahi huzura kavuşabilir. $^{29}$

Yahudi geleneğinde ölü ruhlarıyla ilgili yukarıda bahsettiğimiz dybbuk inanışına benzer başka inanışlar da vardır. Hz. Yakub’un atalarıyla beraber gömülme arzusu ${ }^{30}$ bağlamında dürüst insanın iyi komşusundan ölümden sonra bile iyilik göreceği düşünülmüş; aynı şekilde iki düşmanın da birbirlerine yakın gömülmemeleri zira ruhlarının birbirlerine rahat vermeyeceklerine inanılmıştır. Yazarı belli olmamakla birlikte Regensburglu Rabbi Judah ben Samuel'e (1150-1217) atfedilen ve Almanya, Kuzey Fransa ve İngiltere’deki Yahudi alt-kültürüne yeni bir yaklaşım getiren Aşkenaz

27 David Samuel Goyer, The Unborn [Doğmamış], (Film, 2008), 00:39:00-00:39:16.

28 J. H. Chajes, "Dybbuk", Encyclopedia of Religion, ed. Lindsay Jones (ABD: Thomson Gale, 2005), 4/2533.

29 İsmail Taşpınar, Duvarın Öteki Yüzü: Yahudi Kaynaklarına Göre Yahudilik’te Ahiret Inancı, (İstanbul: Gelenek Yayıncılık, 2003), 245.

30 Yar.47:30. 
Yahudi kitaplarıyla ilgili bir çalışma olan Sefer Hasidim'de, ${ }^{31}$ ölmekte olan bir insana güvensizlik duymak için hiçbir sebep olmadığı zira ölünün kesinlikle intikamını alacağı iddia edilmiştir. Talmud dönemlerinde de ölünün mezarı başında toplanan 10 kişinin hayattayken ona yapılan yanlışlar için özür dilemesi geleneğinden bahsedilmiştir. ${ }^{32}$

Filmde ise “dybbuk” cennete girmesi yasaklanan kötü ruh olarak tanımlanmış ve iki dünya arasında geçiş kapısı olarak kullanabilmek için kendine yeni bir beden aradığından bahsedilmiştir. Bu süreç içerisinde de nispeten zayıf yaşam formları olan böceklerin veya hayvanların bedenlerinden geçerek en çok arzuladığı şey olan ikiz kardeşlerden birinin bedenini ele geçirmeyi planladığı anlatılmıştır. Bahsi geçen dybbuk ilk olarak, Nazilerin Auschwitz toplama kampında üzerinde yapılan deneyler sonucu hayatını kaybeden Casey’nin büyük dayısının (anneannenin ikizi) bedenine girerek onun tekrar dirilmesini sağlar. Ancak ikiz kardeşinin artık eski halinde olmadığını fark eden Casey’nin anneannesi, kardeşini öldürür. Casey’nin annesinin bir ikizi olmadığı için dybbuk, Casey’nin anne karnındaki ikiz kardeşinin bedenine girmiştir. İkizinin Casey’nin göbek kordonunun boynuna dolanması sonucu anne karnında ölmesiyle dybbuk artık Casey’yi rahatsız etmeye ve onun karnındaki çocuğunun bedenine girmeye çalışmaktadır. ${ }^{33}$ Yardım almak için anneannesiyle görüşen Casey’ye anneannesi şeytan çıkarma ayinlerinin bulunduğu Sefer Ha-Mar'ot (Aynalar Kitabı) isimli bir kitaptan bahseder. ${ }^{34}$ Tam ismi Sefer Mar'ot ha-Zove'ot olan bu kitabın yazılış tarihi tam olarak bilinmemektedir. Kitap ismini Tevrat’taki “Buluşma Çadırı’nın giriş bölümünde hizmet eden kadınların aynalarından tunç ayaklıklı tunç bir kazan yaptı.”35 ifadesinden almaktadır. Mar'ot ha-Zove’ot'un Ortaçağ Yahudi edebiyatında yüce ruhların Tanrı’yı görmelerini ve O’nun tarafından görülmelerini sağladıkları düşünülmüştür. Onların ruhun ve Tanrı’nın görüntülerini geri ve ileri olarak yansıttıkları tasavvur edilmiştir. “Ayna” veya “vizyon” manasına gelen mar’ah kelimesi, Musa’nın peygamberi

31 Ivan G. Marcus, Sefer Hasidim and the Ashkenazic Book in Medieval Europe, (ABD: University of Pennsylvania Press, 2018), 1.

32 Joshua Trachtenberg, Jewish Magic and Superstition: A Study in Folk Religion, (ABD: Behrman's Jewish Book House, 1939), 63.

33 Goyer, The Unborn, 00:40:09-00:40:38.

34 Goyer, The Unborn, 00:41:09-00:41:20.

35 Çık.38:8. 
vizyonunu tanımlamak için Rabbinik literatürde kullanılmış olan ve "parlayan ayna” anlamına gelen “ispaqlareyah ha-me’irah” ifadesini hatırlatmaktadır. ${ }^{36}$

Filmde ikizler bir tür ayna olarak tasvir edilmişler ve aynalar da maddi dünyadan metafizik aleme açılan kapılar olarak görülmüşlerdir. ${ }^{37}$ Casey’nin anneannesi, bedenini ele geçiren bir dybbuk’tan dolayı ölümden dirilen ikiz kardeşini öldürmüştür. ${ }^{38}$ Casey’nin ikizi ise anne karnında Casey’nin göbek bağının boynuna dolanması sonucu ölmüştür. Dolayısıyla Casey’nin de dolaylı yoldan kardeşini öldürdüğü ima edilmeye çalışılmıştır. ${ }^{39}$ İkizlerle alakalı Yahudilik’te ve etik düalizmin hâkim olduğu Mecûsîlik başta olmak üzere çeşitli dinsel geleneklerde birtakım inanışlar bulunmaktadır. Tevrat’ta Yakub ve Esav, anneleri Rebeka'nın karnında bile sürekli itişen ${ }^{40}$ ve Esav mücadeleden vazgeçip başka bir yere göç edene kadar birbirleriyle sürekli mücadele halinde olan ikizler olarak anlatılırlar. ${ }^{41}$ Mecûsîlik'te Zerdüşt'e atfedilen Gathalarda hayatın ve ölümün atfedildiği ikiz ruh’tan bahsedilmektedir. Bu ikiz ruh meselesi Ahura Mazda’nın (Ohrmazd) yegâne tanrı mı olduğu yoksa kötülüğün kaynağı olarak kabul edilen Angra Mainyu'yla (Ehrimen) bu tanrısallığı paylaşmakta mı olduğuna dair tartışmanın kökeninde yatan meseledir. ${ }^{42}$ Zira Zaman Tanrısı Zürvan’dan çıkan ikizler olarak tasvir edilen Ohrmazd ve Ehrimen, Gatalarda simetrik ve mükemmel bir şekilde iyilik ve kötülük olmak üzere iki zıt öze sahip ve sürekli mücadele halinde olan kuvvetleri temsil etmektedir. ${ }^{43}$ İkizlerle alakalı bu inanışların temelinde Yin Yang, Gnostik Düalizm, diyalektik materyalizm gibi düşünce sistemlerinde bulunan, her şeyin zıddıyla kaim olduğu, sürekli bir değişim ve birbirleriyle sürekli bir mücadele halinde olduğu ile ilgili düşüncenin olması muhtemeldir.

36 David ben Yehudah he-Hasid, The Book of Mirrors: Sefer Mar'ot ha Zove'ot, ed. Daniel Chanan Matt (ABD: Scholars Press, 1982), 9.

37 Goyer, The Unborn, 00:39:18-00:39:32.

38 Goyer, The Unborn, 00:39:37-00:40:06.

39 Goyer, The Unborn, 00:21:02-00:21:18.

40 Yar.25:22.

41 Yar.25, 27, 32, 33.

42 Mehmet Alıcı, Kadîm Iran'da Din: Mecûsî Geleneğinde Tektanrıcılık ve Düalizm İlişkisi, (İstanbul: MilelNihal Yayınları, 2021), 47-48.

43 Ugo Bianchi, "Twins", Encyclopedia of Religion, ed. Lindsay Jones, (ABD: Thomson Gale, 2005), 14/9412. 
Başroldeki kız olan Casey’ye anneannesi Joseph Sendak isimli bir rabbiden yardım almasını tavsiye eder. Casey’nin Rabbi Sendak ile olan görüşmesinde Sendak’ın Casey’ye kötü ruhlarla ilgili söylediği şeyler dikkat çekicidir. Sendak, folklorun dışında dybbuk diye bir şeyin olmadığını ifade edip ruh ve şeytan gibi şeyleri Ortaçağ’da insanların tam olarak teşhis edemedikleri durumları tıkıştırdığı bir öteberi çantasına benzetmektedir. Yani Sendak, insanların tanımlayamadıkları ve anlamlandıramadıkları durumlar konusunda sadece ruh ve şeytan gibi fenomenlere sığındıklarını ifade etmeye çalışmıştır. O dönemlerde henüz akıl hastalıklarının bile bilinmediğinden bahsederek dybbuk fenomenini bilinmeyenin bir açıklaması olarak görmüştür. ${ }^{44}$ Bu açıklama aynı zamanda mitlerin antik dönemdeki işlevleri arasında zikredilmektedir.

Filmde kötü ruhlara karşı korunma öğeleri olan bazı tılsım ve amuletler de dikkat çekmektedir. Bunlardan birisi Fatmaana Eli olarak da bilinen ve Arapça’da “beş” manasındaki Hamsa'dır. Anneannesi Miriam’ın Eli diye bahsettiği tılsımı bir korunma nesnesi olarak Casey’ye verir. ${ }^{45}$ Yahudi geleneğinde de Hz. Musa ve Hz. Harun'un kardeşi Miriam’a atfen Miriam’ın Eli; “beş” manasında da “hameş” olarak bilinir. Yahudi halk inancında 6 köşeli Davut yıldızının ortasına yerleştirilerek kolye şeklinde taşınır. Her türlü metalden yapılabilen, Müslümanlar arasında nazara karşı tılsım olarak kullanılan ve cömertlik, misafirperverlik, güç ve ilahi takdir gibi manalar da atfedilen bu tılsım ${ }^{46}$ Müslüman ve Yahudi kültürlerinden çok daha önce, eli kötü ruhları uzaklaştıran bir Ortadoğu tanrıçasına dayandırılır. ${ }^{47}$ Eski Mezopotamya’da göz ve el resimlerinin koruyucu işaretler olarak kullanıldığı bilinmektedir. ${ }^{48}$

Öte yandan, filmin bir sahnesinde Casey’nin okkült konulara ilgisi olan yakın arkadaşı Casey’ye kötü ruhlardan korunmak için bir makası yatarken ağzı açık bir şekilde yastığının altına koymasını tavsiye etmekte ve bunu büyükannesinden öğrendiğini ifade etmektedir. ${ }^{49}$ Buna paralel olarak pek çok kültürde demirin, metallerin

44 Goyer, The Unborn, 00:44:11-00:44:44.

45 Goyer, The Unborn, 00:46:03-00:46:09.

46 William Thomas - Kate Pavitt, The Book of Talismans, Amulets and Zodiacal Gems, (Global Grey, 2013), 63 .

47 https://www.luckymojo.com/hamsahand.html (Erişim Tarihi 24.2.2021).

48 Zbinden, Cin ve Ruh İnançları, 128.

49 Goyer, The Unborn, 00:33:35-00:33:54. 
ve demir veya herhangi bir metalden yapılmış nesnelerin kötü ruhlara karşı korunma sağladığı inancı vardır. Çerkez inanışlarında demir bıçak demonları (cinleri) uzaklaştırır. $^{50}$ Kuzey İskoçya'da demirin hatta daha da iyisi çeliğin peri ırkına karşı büyük bir koruyucu olduğuna inanılır. Kılıç, bıçak, tüfek namlusu veya her ne şekilde olursa olsun metallerin bu amaç için çok güçlü olduğu düşünülmüştür. Bir perinin evine girildiğinde her zaman kapıya bıçak, iğne veya olta çengeli gibi bir parça çelik yapıştırılmasının eve giren kimse çıkmadan perilerin kapıyı kapatamaması için gerekli olduğu belirtilmiştir. ${ }^{51}$ Türk halk inançları arasında da Albastı adı verilen kötü ruhlara karşı lohusa kadını ve yeni doğmuş bebekleri korumak için yastıklarının altına Kur’an, muska ve makas konulur. ${ }^{52}$

Görevli olduğu sinagogun içerisinde kafası ters dönmüş bir köpeğin bedeninde kendisine bir dybbuk görünmesinden sonra ${ }^{53}$ Casey’ye eksorsizm ritüeli uygulama konusunda ikna olan Rabbi Sendak’ın bu ritüel için yardım istediği eski dostu Protestan rahibi Arthur Wyndham eksorsizm ritüellerinin doğası hakkında bazı kayda değer açıklamalar yapmaktadır. Wyndham, Casey’nin kendisine bulaştığını düşündüğü “şey”in muhtemelen bütün dinlerden ve hatta insanoğlundan bile daha eskiye dayandığını iddia etmektedir. ${ }^{54}$ Wyndham'ın bahsettiği “şey”, Şeytan veya diğer adıyla İblis’tir. Fransız yazar Gerald Messadie Şeytan’ın Genel Tarihi adlı kitabında Devrim’den sonraki İran’ın fiili başkanı Ayetullah Humeyni’nin Amerika Birleşik Devletleri’ni “Büyük Şeytan” şeklinde nitelemesinden ve eski Amerikan Başkanı Ronald Reagan'ın Sovyetler Birliği’ni “Kötülük İmparatorluğu” olarak addetmesinden bahseder. ${ }^{55}$ Messadie burada “öteki”yi ifade etmenin yollarını örneklemektedir. Verilen örneklerde Şeytan'ın tıpkı Yahudilik’te, Hıristiyanlık’ta, İslam'da ve bazı düalist dinlerde Tanrı’nın karşısında yer alan bir “teolojik öteki” olması gibi politik “öteki”nin

50 Mircea Eliade, Demirciler ve Simyacılar, çev. Mehmet Emin Özcan, (İstanbul: Kabalcı Yayınevi, 2003), 226.

51 James George Frazer, The Golden Bough: A Study in Magic and Religion Part II - Taboo and the Perils of the Soul, (İngiltere: Macmillan and Co., 1911), 232.

52 Mustafa Ünal, "Ruhani (Görünmeyen) Varlıklarla İlgili İnanışlar", Halk İnanış̧ları El Kitabl, ed. Durmuş Arık - Ahmet Hikmet Eroğlu, (Ankara: Grafiker Yayınları, 2017), 358.

53 Goyer, The Unborn, 01:00:00-01:00:33.

54 Goyer, The Unborn, 01:06:28-01:06:36.

55 Gerald Messadie, Şeytan'ın Genel Tarihi, çev. Iş̧ı Ergüden, (İstanbul: Kabalcı Yayınevi, 1998), 8. 
konumlandırılmasında bir araç olarak kullanıldığını görüyoruz. Filmdeki karakter olan Wyndham'ın ifadelerinde ise Casey’nin kendisine bulaştığını düşündüğü şeytan veya şeytani güçler, farklı varlık düzleminde yer alan ontolojik bir "öteki” olarak karşımıza çıkmaktadır.

Aynı diyalog içerisinde Wyndham, bir şeytan türünün Yahudi duasına karşı savunmasız olması veya başka bir şeytan türünün Hıristiyan veya Müslüman duasına alerjik olması gibi bir durum olmadığını belirterek Casey’nin inançsız olabileceğini ancak onun annesinin ve anneannesinin inancı olduğunu ve duada telaffuz edilen kelimelerin işe yaramasına yardım eden şeyin inanç olduğunu ifade etmiştir. ${ }^{56}$ Burada inancın tıptaki Plasebo etkisine ${ }^{57}$ benzer bir şekilde etki edebileceğini görmekteyiz. Yani bir kişi gerçekte cin, şeytan veya kötü ruhların etkisinde olmasa bile kişinin sahip olduğu inancın tıpkı Plasebo etkisinde olduğu gibi kurbanın kendi psikolojisini, etkisi altında olduğunu düşündüğü kötü ruhtan kurtulmaya kanalize edebileceğini düşünebiliriz.

Casey, eksorsizm ayininin nerede ve ne zaman yapılacağını sorduğunda Rabbi Sendak Şabat günü olacağını belirtir. Ancak ayinin sinagogda olacağını düşünen Casey’ye eksorsizm ayininin “ortodoks olmayan” bir şey (unorthodox) olmasından dolayı başka bir yerde olması gerektiğini söyler. ${ }^{58}$

Yahudi geleneğindeki eksorsizm ayini dünyalar arasında bir koridor açtığı için ayinin, ölülerin dünyasıyla temas kurmanın tehlikelerini de beraberinde getireceği belirtilmiş ve kaos ve ölüm korkusuyla mücadele edebilmek için bazı katı ayinsel kurallara uymanın gerekli olduğu aktarılmıştır. Sinagogdaki ibadet için gerekli görülen 10 yetişkin erkekten oluşan yeter sayı (minyan), Yahudi geleneğindeki şeytan çıkarma ayininde de şart koşulmuştur. Bu 10 yetişkin erkeğin kefen benzeri beyaz bir elbise ve dua şalı giyip muska takmaları gerekmektedir. Bundan sonra Sandık açılır, koç boynuzundan yapılmış yedi şofar aynı anda çalınır, yedi Tevrat rulosu Sandık’tan

56 Goyer, The Unborn, 01:06:36-01:07:08.

57 Bilinen herhangi bir farmakolojik etkisi veya değeri olmayıp gerçek ilaca benzer şekilde üretilerek fizyolojik ve psikolojik tedavide kullanılan maddelerdir. Ayrıntılı bilgi için bkz.: Bonnie Strickland, The Gale Encyclopedia of Psychology, (ABD: Gale Group, 2001), 502. 
çıkarılır, yedi siyah mum yakılır, siyah bir perde Sandık’ın üzerine örtülür, tütsü yakılır, şeytanları ve kötü ruhları tehdit eden dilekler, lanetler ve aforozlar okunur. Bütün cemaat lanetleri, aforoz formülünü ve anti-şeytani bir şiiri tekrar eder. $\mathrm{Bu}$ şiir Mezmurlar 91 veya Hekhalot literatüründe “Aleinu le-şabeah” olarak açıklanan eski bir duadır. Daha sonra ayine katılanlar “şeytanı parçalamak” manasına gelen "kera satan” ifadesini içeren 42 harfli ilahi ismin 7 farklı kombinasyonunu okurlar. Eksorsizm töreni, kutsallık ve kirlilik, kutsal isimler ve ölüler dünyasından sesler, yaşayanlar dünyasının kendilerini kutsayan ve arındıran temsilcileri ve ölüler dünyasının düzeni kirleten ve alt üst eden görünmez elçileri arasındaki savaşa odaklanır. ${ }^{59}$

Filmin son kısmında geleneksel Yahudi şeytan çıkarma ayini ile alakalı yukarıda bahsedilen unsurların bir kısmının uygulandığını görmekteyiz. Rabbi Sendak, Yahudi eksorsizminin 10 kişiyle yapılması gerektiğini ifade edip bu sayıyı da 10 parmak, 10 Emir ve Kabala mistisizminde merkezi bir yer işgal eden 10 Sefirot ile ilişkilendirmektedir. ${ }^{60}$ Tanrı’nın özelliklerinin görünür dünyadaki tezahürleri olan 10 Sefirot, Taç (Alçakgönüllülük), Anlayış, Bilgelik, Yargı, Sevecen İyilik, Güzellik, Haşmet, Tahammül, Temel ve Hakimiyet olarak sıralanmaktadır. ${ }^{61}$

Ayin başlamadan önce 10 kişi, ortasında ayin yapılacak kişi olan Casey’nin durduğu koruyucu bir daire oluşturur. Wyndham, Sendak’ın orijinal İbranca metni okuyacağını ve ayinin diğer üyelerinin de İngilizce metinden Sendak’ın okuduklarını tekrar edeceklerini belirtir. Sendak ayinin kalbinin 91. Mezmur (Yoshev B’seter) olduğunu söyler. Ayinin başında ve sonunda şofarı üfleyeceğini ve şofarın, kurbanın bedeninde gizlenmiş olan dybbuk’u şoka uğratacağını ve bedenden çıkmak için hassas hale gelmesini sağlayacağını ifade eder. Ruh daha itaatkar olduğunda ise onu çıkarmaya başlayacaklarını belirtir. Bu sırada da ayinin diğer üyelerinin en hassas durumda

59 Rachel Elior, Dybbuks and Jewish Women in Social History, Mysticism and Folklore, çev. Joel Linsider, (Kudüs: Urim Publications, 2011), 104-105.

60 Goyer, The Unborn, 01:09:04-01:09:14.

61 Perle Epstein, Kabala: Musevi Mistiklerinin Yolu, çev. Nusret Karayazgan - Şiyma Barkın, (İstanbul: Dharma Yayınları, 2000), 18. 
olacağını zira her ne kadar kötü ruh Casey’yi istese de fırtınada herhangi bir limana sığınabileceğini ifade eder. ${ }^{62}$

Ayin başlamadan önce Sendak, Casey’ye uyarılarda bulunur. Her ne kadar manevi bir fenomen olsa da dybbuk’un fiziksel bir kütleye ihtiyaç duyacağını hatırlatıp eğer vücudu tepki verirse eksorsizm ayininin işe yarayacağını belirtir. Bundan sonra Rabbi Sendak şofarı 3 defa üfleyerek dairenin oluşturulduğunu ve kutsandığını söyler. “İsrail Tanrısı Adonay’ın adıyla, sağımda Michael, solumda Gabriel, önümde Uriel, arkamda Raphael, ayaklarımın altında kutsal topraklar.” ifadeleri ile başlayarak Kutsal Kitap’tan Mezmurlar bölümünün 91. Mezmurunu okumaya başlar. ${ }^{63}$ Mezmurun metni şu şekildedir:

Yüceler Yücesi'nin barınağında oturan,

Her Şeye Gücü Yeten'in gölgesinde barınır.

“O benim sığınağım, kalemdir” derim RAB için,

“Tanrım'dır, O'na güvenirim.”

Çünkü O seni avcı tuzağından,

Ölümcül hastalıktan kurtarır.

Seni kanatlarının altına alır,

Onların altına sığınırsın.

O'nun sadakati senin kalkanın, siperin olur.

Ne gecenin dehşetinden korkarsın,

Ne gündüz uçan oktan,

Ne karanlıkta dolaşan hastalıktan,

Ne de öğleyin yok eden kırgından.

Yanında bin kişi,

62 Goyer, The Unborn, 01:09:19-01:09:58.

63 Goyer, The Unborn, 01:11:12-01:12:20. 
Sağında on bin kişi kırılsa bile,

Sana dokunmaz.

Sen yalnız kendi gözlerinle seyredecek,

Kötülerin cezasını göreceksin.

Sen RAB'bi kendine sığınak,

Yüceler Yücesi'ni konut edindiğin için,

Başına kötülük gelmeyecek,

Çadırına felaket yaklaşmayacak.

Çünkü Tanrı meleklerine buyruk verecek,

Gideceğin her yerde seni korusunlar diye.

Elleri üzerinde taşıyacaklar seni,

Ayağın bir taşa çarpmasın diye.

Aslanın, kobranın üzerine basıp geçeceksin,

Genç aslanı, yılanı çiğneyeceksin.

"Beni sevdiği için

Onu kurtaracağım” diyor RAB,

“Beni iyi tanıdığı için

Ona kale olacağım.

Bana seslenince onu yanıtlayacağım,

Sıkıntıda onun yanında olacağım,

Kurtarıp yücelteceğim onu.

Onu uzun ömürle doyuracak,

Ona kurtarışımı göstereceğim.”“4

64 Mez.91. 
Sendak’ın Korunma Mezmuru olarak bahsettiği, Kutsal Kitap’ta ise Tanrı Adamı Musa'nın Duası olarak geçen bu mezmurda görüldüğü gibi sığınak ve kale şeklinde nitelenen Rabb’in Musa’nın şahsında İsrailoğullarını emrindeki meleklerle gittikleri her yerde koruduğu ve meleklerin onların ayaklarına taş değmesin diye elleri üzerinde taşıdıkları anlatılmaktadır. Rabbinik literatürde Tanrı’nın tahtının dört tarafında oturan ve “Göklerin Göğü” olan Tanrı’nın Sarayı’na diğer bütün meleklerin aksine serbest bir şekilde girip çıkabilen melekler olarak resmedilen Michael, Gabriel, Uriel ve Raphael ${ }^{65}$ filmde Sendak tarafından okunan 91. Mezmur’un girizgahında sanki kişinin dört tarafında durarak onu koruyan koruyucu meleklermiş gibi tasavvur edilmiştir. Devamında ise Musa'nın ne gecenin dehşetinden, ne gündüz uçan oktan, ne karanlıkta dolaşan hastalıktan ne de öğleyin yok eden kırgından korktuğundan bahsedilmiş ve yanında bin kişi, sağında onbin kişi kırılsa bile ona hiçbir zarar gelmeyeceği ifade edilmiştir. Filmin son kısmında eksorsizm anında bedenden bedene geçerek geçtiği bedenleri öldüren veya onlara zarar veren dybbuk, tıpkı bu cümlelerde ifade edildiği gibi Casey’ye hiçbir zarar verememektedir. ${ }^{66}$

Eksorsizm sahnesinde bahsi geçen 10 kişinin Casey’nin etrafında koruyucu ve kutsal bir daire oluşturması dikkat çekici bir unsurdur. Sümerlilerin dünyada yazıya geçirilmiş ilk destan olduğu düşünülen Gılgamış Destanı'nda Gılgamış ve arkadaşı Enkidu, orman devi Humbaba’yı öldürmeye giderlerken mola verdikleri bir sırada Enkidu, Gılgamış için bir şeyler okuyup üfledikten sonra onu yatırıp çevresine büyülü bir çember çizer. ${ }^{67}$ Yezidi inancında bir insan veya mekan başkası tarafından daire içine alınırsa o daireye kimsenin giremeyeceği veya kimsenin daireden çıkamayacağı anlatılmıştır. $^{68}$ Viktoryen dönemin meşhur romancılarından İrlandalı yazar Bram Stoker’ın (1847-1912) dünyaca ünlü romanı Dracula'da vampir avcısı Van Helsing, ana karakterlerden olan Bayan Mina’nın etrafına “kutsal” bir daire çizer ve dairenin içine

65 Joshua Gutmann, "Angels and Angelology", Encyclopedia Judaica, ed. Fred Skolnik (ABD: Thomson Gale, 2007), 2/153.

66 Goyer, The Unborn.

67 Gılgamış Destanı, çev. Sait Maden, (İstanbul: Türkiye İş Bankası Kültür Yayınları, 2018), 41.

68 Nurullah Ulutaş - Şener Şükrü Yiğitler, "Murathan Mungan’ın Mezopotamya Üçlemesinde (Mahmud ile Yezida, Taziye ve Geyikler Lanetler) Metin Dışı Sözlerin Oyuna Katkısı, Edebiyatta Jest ve Mimik, ed. Ümral Deveci - Ahmet Akgöl (İstanbul: Kitabevi Yayınları, 2020), 284. 
Kutsal Ekmek kırıntıları serperek daireyi dokunulmaz ve kutsal bir alan haline getirir. Bayan Mina’ya zarar vermek için gelen üç vampir kadın bu kutsal daire içinde duran Mina ve Van Helsing’e yaklaşamadığı için ikisi kendilerini dairenin içinde güvende hissederler. Daireyi oluşturup kutsayan Van Helsing dairenin içine girip çıkabiliyorken Mina dairenin dışına çıkamaz ve vampirler de daireye giremezler. ${ }^{69}$ Malleus Maleficarum'da da ahır kapısının üzerine asılan ve ahırdaki hayvanları büyüden koruyor olabileceği düşünülen bir halkadan bahsedilmektedir. ${ }^{70}$ Kutsal daire inanışıyla ilgili buna benzer örnekler çoğaltılabilir. Filmdeki eksorsizm sahnesinde amaç 10 kişiden oluşan "kutsal” dairenin içinde bulunan ve kutsal olmayan (profan) varlığı (dybbuk) ait olmadığı o kutsal alandan çıkarmaktır. Bu kutsal daire inanışını kutsal olanla kutsal olmayan ya da metafizik alemle fiziksel alem arasına bir sınır çizmek olarak düşünebiliriz.

Casey’nin karnındaki bebeğin vücudunu henüz tam olarak ele geçirememiş olan dybbuk, ayinde 91. Mezmur okunurken ilk olarak bir böceğin bedeninde görünür ve daha sonra sırasıyla Rahip Wyndham ve Casey’nin erkek arkadaşı olan Mark’ın bedenine girerek Casey’nin karnındaki bebeğin bedenini tamamen ele geçirmeye çalışır. Ayinin diğer üyelerini etkisiz hale getiren dybbuk, Rabbi Sendak ve Casey’nin 91. Mezmur'u beraber okuyup tamamlamasıyla bedenden bedene dolaşarak geldiği Mark’ın bedeninden çıkarılarak tamamen kovulmuş olur. ${ }^{71}$

Bahsi geçen eksorsizm ayininde görüldüğü gibi bir şeytanın veya cinin belirli bir kişinin bedenini ele geçirdiği veya ona rahatsızlık verdiği düşünülerek sadece mevzubahis kişiye uygulanan ve daha çok bilinen eksorsizm ayinlerinin aksine bu ayinde şeytan veya cin olmayıp kötü veya günahkâr bir ruh olarak tanımlayabileceğimiz dybbuk, hedef almış olduğu bedene tam olarak yerleşmeyi başarana kadar nispeten aciz yaşam formları olan hayvan bedenleri de dahil olmak üzere farklı bedenlerde gezmektedir. Dolayısıyla uygulanan eksorsizm ayininin nesnesi olan beden de sürekli olarak değişmektedir. Cinlerin farklı hayvanların suretine büründüğüne yönelik var olan

Bram Stoker, Dracula, çev. Niran Elçi, (İstanbul: İthaki Yayınları, 2018), 409-411.

Kramer, Malleus Maleficarum, s. 387.

71 Goyer, The Unborn, 01:13:28-01:19:29. 
halk inanışlarının farklı bir yansıması, bahsi geçen dybbuk’un filmde köpek, böcek gibi varlıkların bedenlerine girip o varlıkların suretlerinde görünmesi şeklinde karşımıza çıkmaktadır. ${ }^{22}$

\section{Sonuç}

Metafizik alem, tarih boyunca insanoğlunun hep merakını cezbetmiştir. Bu varlıklarla farklı ilişkiler, etkileşimler ve bağlantılar üzerine birçok hikâye anlatılmış, birçok mit ihdas edilmiştir. Makalemizin konusunu oluşturan Yahudi geleneğinde şeytan/cin çıkarma teması ise The Unborn adlı sinema filmi bağlamında incelenmiş ve filmde kullanılan birçok unsurun Yahudi eksorsizm geleneğiyle örtüştüğü görülmüştür. Filmin yapımcısı ve senaristi David S. Goyer, kendisi de bir Yahudi olması dolayısıyla Yahudi geleneğine ve folklorüne aşinalığını filmde çok bariz şekilde kullandığı dînî, geleneksel ve folklorik unsurlarla ortaya koymuştur. Bu unsurlardan en önemlisi olan, sinagogda ibadet için gerekli görülen ve Bar Mitzvah töreniyle yetişkinliğe adım atmış 10 erkekten oluşan yeter sayı (minyan), Yahudi eksorsizm geleneğinde de şart koşulmuş ve filmde de Tanrı’nın görünür özellikleri olup Kabalacı sudur anlayışı çerçevesinde dünyanın yaratılışını sağlayan 10 ilahi isimle (10 Sefirot) ve Hz. Musa’ya indirilen 10 Emir’le ilişkilendirilerek yerini almıştır.

Filmin son kısmında eksorsizm ayini esnasında Kitab-ı Mukaddes’in Mezmurlar kitabından 91. Mezmurun okunduğunu görüyoruz. Filmde Korunma Mezmuru olarak bahsedilen bu mezmur Kitab-ı Mukaddes’te Tanrı Adamı Musa'nın Duası olarak geçmektedir. Bu duada adları anılan ve Rabbinik literatürde dört büyük melek olarak addedilen Michael, Gabriel, Uriel ve Raphael ise filmdeki eksorsizm sahnesinde koruyucu figürler olarak kabul edilmiştir.

Bunların dışında gerek Yahudi folklorunda gerekse diğer kültürlerde bulunan Fatmaana Eli/Miriam'ın Eli amuleti ve metallerin veya metalden yapılmış nesnelerin cinlere ve kötü ruhlara karşı koruma sağladığına yönelik inanışlar, koruyucu çember inanışları da filmde karşımıza çıkan dikkat çekici unsurlardır. Cinlerin veya şeytanların halk hikayelerinde farklı hayvanların suretlerinde insanlara göründüğü inancı ise bu 72 Goyer, The Unborn, 00:40:34-00:41:09. 
filmde kötü ruh olan dybbuk’un köpek ve böcek gibi hayvanların bedenlerinde tezahür etmesi şeklinde karşımıza çıkmıştır.

İzleyiciyi klişelerle ve modası geçmiş numaralarla korkutmaya çalıştığı yönünde eleştiriler alan filmin 4.8 olan IMDB puanı da her ne kadar düşük gibi gözükse de korku filmlerinin çok yüksek puan alamadığı bir sinema dünyasında çok da kötü sayılmaz. Filmin Yahudi asıllı yönetmeni ve senaristi David S. Goyer, Yahudi geleneği ve folklorundaki eksorsizm, kötü ruh/şeytan ve tılsımlarla ilgili unsurları filmde başarılı sayılabilecek bir şekilde işlemiştir. 


\section{Kaynakça}

Alıc1, Mehmet. Kadîm Iran'da Din: Mecûsî Geleneğinde Tektanrıcılık ve Düalizm Illişkisi, İstanbul: MilelNihal Yayınları, 2021.

Bianchi, Ugo. "Twins". Encyclopedia of Religion. Ed. Lindsay Jones. 14/9411-9418. ABD: Thomson Gale, 2. Basim, 2005.

Ben Yehudah he-Hasid, David, The Book of Mirrors: Sefer Mar'ot ha Zove'ot. ed. Daniel Chanan Matt, ABD: Scholars Press, 1982.

Chajes, J. H. "Dybbuk", Encyclopedia of Religion. Ed. Lindsay Jones. 4/2533-2535. ABD: Thomson Gale, 2. Basim, 2005.

Eliade, Mircea, Demirciler ve Simyacılar. çev. Mehmet Emin Özcan. İstanbul: Kabalcı Yayınevi, 2003.

Elior, Rachel. Dybbuks and Jewish Women in Social History, Mysticism and Folklore. çev. Joel Linsider. Kudüs: Urim Publications, 2011.

Epstein, Perle. Kabala: Musevi Mistiklerinin Yolu. çev. Nusret Karayazgan ve Şiyma Barkın. İstanbul: Dharma Yayınları, 2000.

Frazer, James George. The Golden Bough: A Study in Magic and Religion Part II Taboo and the Perils of the Soul, İngiltere: Macmillan and Co., 1911.

Gılgamış Destanı, çev. Sait Maden. İstanbul: Türkiye İş Bankası Kültür Yayınları, 2018.

Goyer, David Samuel. The Unborn [Doğmamıs] (Film, 2008). https://www.imdb.com/title/tt1139668/?ref_=nv_sr_srsg_0

Gutmann, Joshua. "Angels and Angelology". Ed. Fred Skolnik. 2/152-155. Encyclopedia Judaica. ABD: Thomson Gale, 2. Basım, 2007.

Gündüz, Şinasi. Din ve Inanç Sözlüğü. İstanbul: Vadi Yayınları, 2. Basım, 2017.

Hillers, Delbert Roy, "Demonology”, Encyclopedia Judaica, Ed. Fred Skolnik. 5/572574. ABD: Thomson Gale, 2. Basim, 2007.

Klein, Ernest. A Comprehensive Etymological Dictionary of the English Language. 1/437. Hollanda: Elsevier Publishing Company, 1966, 2. Basim.

Kramer, Heinrich, The Hammer of Witches: A Complete Translation of the Malleus Maleficarum. ABD: Cambridge University Press, 2009.

Liddell, Henry George - Scott, Robert. A Greek-English Lexicon. Oxford: Clarendon Press, 10. Basim, 1996.

Marcus, Ivan G. Sefer Hasidim and the Ashkenazic Book in Medieval Europe. ABD: University of Pennsylvania Press, 2018.

Messadie, Gerald. Şeytan'ın Genel Tarihi. Çev. Işık Ergüden. İstanbul: Kabalcı Yayınevi, 1998. 
Pierce, J. M. "Roman Ritual". New Catholic Encyclopedia. 12/258. ABD: Thomson Gale, 1. Basim, 2003.

Rituale Romanum. Ed. J. Lecoffre, vd. ABD: 1855.

Scognamillo, Giovanni - Arslan, Arif. Doğu ve Batı Kaynaklarına Göre Şeytan. İstanbul: Karizma Yayınları, 1999.

Stoker, Bram. Dracula. çev. Niran Elçi. İstanbul: İthaki Yayınları, 2018.

Strickland, Bonnie (Ed.), The Gale Encyclopedia of Psychology, 502. ABD: Gale Group, ABD, 2001.

Taşpınar, İsmail. Duvarın Öteki Yüzü: Yahudi Kaynaklarına Göre Yahudilik'te Ahiret İnancı. İstanbul: Gelenek Yayıncılık, 2003.

Thomas, William. - Pavitt, Kate. The Book of Talismans, Amulets and Zodiacal Gems, Global Grey, 2013.

Trachtenberg, Joshua. Jewish Magic and Superstition: A Study in Folk Religion, ABD: Behrman's Jewish Book House, 1939.

Ulutaş, Nurullah - Yiğitler, Şener Şükrü. "Murathan Mungan'ın Mezopotamya Üçlemesinde (Mahmud ile Yezida, Taziye ve Geyikler Lanetler) Metin Dış1 Sözlerin Oyuna Katkısı", Edebiyatta Jest ve Mimik, İstanbul: Kitabevi Yayınları, 1. Basim, 2020.

Ünal, Mustafa. "Ruhani (Görünmeyen) Varlıklarla İlgili İnanışlar”. Halk İnanışları El Kitabı. Ed. Durmuş Arık - Ahmet Hikmet Eroğlu. Ankara: Grafiker Yayınları, 2017.

Zbinden, Ernst. İslam'da ve Eski Ortadoğu'da Cin ve Ruh Inançları. çev. Ekrem Sarıç̧ığlu. İstanbul: Yeni Ufuklar Neşriyat, 1994.

Zemahşerî, Ebü'l-Kasım Mahmud b. Ömer b. Muhammed el-Harizmi. el-Keşşaf, 6/507. İstanbul: Türkiye Yazma Eserler Kurumu Başkanlığı Yayınları, 2020. 